\title{
Income convergence between Southeast Europe and the European Union*
}

\author{
Goran Radosavljevićn ${ }^{1}$, Mihajlo Babin ${ }^{2}$, Miloš Erić $^{3}$, \\ Jelisaveta Lazarevic ${ }^{4}$
}

\begin{abstract}
This paper investigates the average gross per capita income convergence of eight Southeast European economies towards the EU average. Our goal is to analyse which factors have driven that convergence in the SEE region and describe convergence paths in the 2000-2018 period, concerning two sub-periods, before and after the economic crisis. We use a combination of parametric and nonparametric methods and a fixed effects linear panel regression with robust standard errors. Results suggest that the EU integration process drove convergence, education level, investment (FDI, private domestic and public investments), and private sector lending, as well as by government expenditures. Economic crisis, unemployment, and inflation were the main factors which have influenced the divergence process. We also concluded that the post-transition growth model dominant in the SEE region, based on an FDI inflow, has not sufficient for income convergence in this region. Private domestic investments are a critical missing factor for faster income convergence.
\end{abstract}

Key words: Gross income convergence, Southeast Europe, economic growth, EU integration, panel data analysis

JEL classification: $F 43,011,047$

\footnotetext{
* Received: 12-10-2020; accepted: 21-12-2020

1 Associate Professor, University Metropolitan, FEFA Faculty, Bulevar Zorana Djindjica 44, 11070 Belgrade, Serbia. Scientific affiliation: Public finance, microeconomics, energy economy. Phone:+381694777605.E-mail: gradosavljevic@fefa.edu.rs.

2 Associate Professor, University Metropolitan, FEFA Faculty, Bulevar Zorana Djindjica 44, 11070 Belgrade, Serbia. Scientific affiliation: Economic development, fiscal policy. Phone: +381694777605.E-mail: mbabin@fefa.edu.rs.

${ }^{3}$ Assistant Professor, University Metropolitan, FEFA Faculty, Bulevar Zorana Djindjica 44, 11070 Belgrade, Serbia. Scientific affiliation: European economic integration, economic development.Phone: +381694777605.E-mail:meric@fefa.edu.rs.

4 Teaching Assistant, University Metropolitan, FEFA Faculty, Bulevar Zorana Djindjica 44, 11070 Belgrade, Serbia. Scientific affiliation: Financial markets, competitiveness. Phone: +381694777605.E-mail: jlazarevic@fefa.edu.rs.
} 


\section{Introduction}

Southeast Europe $(\mathrm{SEE})^{5}$ entered the $21^{\text {st }}$ century as one of the most underdeveloped parts of Europe, with an average gross domestic product (GDP) per capita almost ten times lower than the European Union (EU) average. A deep recession in the early 1990s influenced by the wars in the former Yugoslavia, international sanctions, delay in structural reforms, political instability, lack of investment, and many other factors, negatively affected the economic development of the region at the beginning of the transition process (Bartlett, 2009; Uvalic, 2010).

The region has been recovering since 2000. Some of the reasons for the relatively high growth rates during the 2000-2008 period were the low starting position, significant donor assistance (primarily from the EU), and significant FDI inflow due to the stabilization of the political environment (except for North Macedonia, which was affected by the conflict in 2001). FDI has steadily increased, particularly after 2006, including some significant privatization deals in the telecommunications and banking sector across the region (Uvalic, 2010: 11). Simultaneously, close to $€ 7$ billion of international assistance, both in the form of grants and loans, entered SEE countries in the 2001-2002 period (European Commission, 2003: 5). However, not all countries had the same pace of development, nor did they rebuild their economies with the same success. Romania, Bulgaria and Croatia, for example, have become part of the EU, which has greatly affected their economic development. Despite the significant growth in the previous period, the SEE region is still the least developed region in Europe. That implies that the convergence process was slow and inadequate, which is a starting point for our analysis.

The main goal of this paper is to examine the process of the income convergence between SEE and the EU during the 2000-2018 period. The main hypothesis is that income convergence in SEE countries was slow and inadequate during that period. We will also test the logical assumption that the dynamics of income convergence is faster in the period before the economic crisis and slower in the period after the crisis. The purpose of this paper is also to examine the gross income convergence and divergence factors in the case of the analysed SEE economies. We use gross income as a convergence indicator (although GDP per capita is more predominantly used) because we focus on living standards rather than just on economic growth. At the same time, GDP per capita might substantially decrease or increase within a decade due to migrations or demographic trends without any effects on the convergence of citizens' living standard. Finally, GDP per capita provides data on the productivity of the economy and does not provide enough information on the living standard. Therefore, it is possible that GDP per capita steadily grows and

5 In our analysis we use the IMF and WB definition of SEE which includes Albania, BosniaHerzegovina, Bulgaria, Croatia, North Macedonia, Montenegro, Romania and Serbia. 
converges and that gross income remains unchanged in case large proportions of gross added value is not reinvested or spent in the country.

After a detailed literature review in part two, we explain the research methodology and define the model and variables in part three. Empirical data and analysis are presented in the fourth section, including Kernel distribution dynamics and regression results. We use a combination of parametric and nonparametric methods to study the dynamics of real per-capita income for eighth SEE countries relative to the EU average over the period 2000-2018. First, we estimated the probability density function of per capita income using a kernel estimator and analysed the evolution in their shape to follow convergence tendencies in the SEE countries. Second, using regression analysis we identified the various factors that contribute to or reduce convergence over the selected period. A discussion of the results is given in part five, followed with conclusions in part six.

\section{Literature review}

Gross income convergence has been investigated far less in economic literature than the GDP convergence. The rationale relies on the theoretical concepts that higher GDP growth rates in less developed countries will lead to higher income, and therefore, income convergence will follow economic convergence. Theoretical aspects of growth convergence (Rassekh et al., 2001; Ben-David, 1996; Greasley and Oxley, 1997) provided essential insights into the structure of the convergence process. Growth convergence among regions inside a country and a specific group of countries have also been studied (Linden, 2002; Carlino and Mills, 1996; Zhang et al., 2001; Dobson and Ramlogan, 2002). The analysis of the economic convergence of the U.S. states between 1840 and 1988 proved the existence of $\beta$-convergence - economies further below steady-state position grow faster (Barro and Sala-i-Martin, 1990). Most research papers analysed and measured convergence by using beta and sigma convergence across countries. Beta convergence implies catching up while sigma convergence implies a reduction in disparities (Grela et al. 2017). Beta convergence generates sigma convergence and is a necessary, but not sufficient, condition of sigma convergence. Countries cannot become similar in terms of GDP if poorer ones do not grow faster (Grela et al. 2017). Apart from beta and sigma convergence, literature recognized nominal and real convergence where nominal convergence represents higher uniformity of nominal variables, while real convergence refers to an approximation of economy welfare levels proxied by GDP per capita (Martin et al., 2001: 3).

In the EU, regional linkages have a significant role in the formation of convergence clubs (Borsi and Metiu, 2015). Assessment of 102 EU regions over the period 1995-2000 (Tselios, 2009) proved the presence of conditional 
convergence in income per capita after controlling for educational attainment, unemployment, sectoral composition, spatially lagged growth of income per capita, and regional fixed effects, and that of unconditional convergence in income inequality. The effects of the European integration on regional convergence of 188 regions between 1991 and 2004 have been thoroughly assessed, and conclusions on growth convergence were not unambiguous (De Dominicis, 2014). Research on the existence of convergence of 10 European countries, which accessed the European Union in 2004 (Vojinovic et al. 2009), provided clear conclusions that convergence took place during the examined period 1995-2006. On the other hand, Simionescu (2015: 74) reject the hypothesis of overall convergence in EU28 over 1995-2012. There is also a study showing that economic, socio-political, and policy differences among EU member states reduce the rate of convergence in the EU (Yin et al., 2003: 210). In some countries, growth rates are varying among regions. According to Eckey and Türck (2005: 18) most studies find a low convergence rate of all or some European regions. The result of EU-25 regional income analyses shows regional disparities in both EU-15 and new member states (Paas and Schlitte, 2006: 23). In Croatia, for example, there is a lack of regional convergence and regions with a higher level of public investments had higher growth rates and short and long-term increases in wages and employment (Drezgić, 2011: 55).

Discussion so far draws that there is little empirical reason for the uncertainty that European integration would cause economies to diverge, and real convergence would seem to depend on a country's capacity to international technological spillovers mainly through FDIs (Martin et al., 2001: 1). Therefore, an important group of convergence factors includes the relevance and impact of FDI and trade and financial openness. The level and growth of per capita income did converge as bilateral FDI flow increased between the two countries. This implies that FDI flow is critical in human capital spillover and thus convergence (Choi, 2004). In the case of 8 CEE countries (Kutan and Yigit, 2009: 136), technology transfer facilitates catching up by this group of countries towards EU15 productivity. Scholars also state the dependence of new member states' convergence speed and speed of capital accumulation (Alho et al., 2004: 19). In the case of 35 OECD countries (D'Elia and De Santis, 2019), low- and middle-income countries benefit more from international trade and trade and financial openness. They further reduce the growth gaps across the countries, but not income inequality. There is also a statement that greater financial integration leading to the transfer of capital from rich to poor, but with higher incomes, financial integration plays fewer roles in attracting foreign capital and reducing this growth impulse (Abiad et al., 2007: 26).

Simionescu (2015: 68) pointed out that convergence is an important problem for new EU member states. Niebhur and Schlitte (2004: 175) also state that 
convergence speed has declined since the early period of European integration ... and catching up to the EU average will be a long-term process for the new member states. Important findings on the economic cycles impact on the Eurozone inequality dynamics show country-level differentiability regarding the utilisation of cyclical advantages (Rubinic and Tajnikar, 2020) which creates serious adverse effects on inequality due to the unequal exchange of labour in the Eurozone (Rubinic and Tajnikar, 2019). The focus on the WB region shows that the absolute convergence of the WB countries was much stronger up to 2008 due to lower initial growth at the earlier stage of transition and global economic expansion before the crisis (Krestovska, 2018: 198). In general, the WB region converges to the EU, but real convergence to the EU average is relatively slow (Krestovska, 2018: 200). According to Sanfey and Milatovic (2018: 2) the WB region will need decades to catch up with EU average standards of living, and full convergence will require productivity and investment on a higher level. According to this report, productivity is a fundamental problem of WB region, reflected in underinvestments, undeveloped institutions and the business environment (Sanfey and Milatovic, 2018: 2). Starting with the literature review, our analysis is focused on income convergence, while most of the published literature on the issue is based on GDP per capita convergence. We believe that this innovative approach, rarely used in economic literature in the region, will put a new light on key factors influencing living standard in the SEE. Second, we will not use standard first ( $\beta$-convergence) and second ( $\sigma$-convergence) moments of the income distribution, which fail to characterize the evolution of the entire income distribution over time. Because of the heterogeneity across SEE countries, we will implement a methodology that uses kernel density estimates to examine the shape of the income distribution and distributional dynamics (Nenovsky and Tochkov, 2014). Last but not least, we want to explore one of the main expectations in transition economies that the process of EU integration leads to an increase in the living standard and catching up with income per capita in the EU.

\section{Methodology}

In order to analyse what are the long-run tendencies of incomes, we will start from Quah (1993, 1996a, 1996b and 1997). The nonparametric part of the analysis starts with estimating the probability density function of relative per capita income using a kernel function. Let $X_{1}, \ldots, X_{n}$ be a sample of $n$ identically distributed observations on a random variable $\mathrm{X}$. The density value $f(x)$ at a given point $x$ is estimated by the following kernel density estimator

$$
\hat{f}(x)=\frac{1}{n h} \sum_{i=1}^{n} K\left(\frac{x-X_{i}}{h}\right)
$$


where $h$ denotes the bandwidth of the interval around $x$ and $K$ is the kernel function. ${ }^{6}$ (Li and Racine, 2007). The kernel estimator assigns a weight to each observation in the interval around $x$, with the weight being inversely proportional to the distance between the observation and $x$. The density estimate consists of the vertical sum of frequencies at each observation. The resulting smooth curve allows us to visualize the shape of the distribution of relative per-capita income and detect the presence of "convergence clubs" represented by modes.

Second, we attempt to identify the determinants of relative per capita income growth via regression analysis. For this purpose, we estimate the following model:

$$
\begin{aligned}
& \Delta \ln \left(\frac{y_{i t}^{S E E}}{y_{t}^{E U}}\right)=\alpha_{i}+\beta_{1} U N E M P L_{i t}+\beta_{2} S C H_{i t}+\beta_{3} F T R_{i t}+ \\
& \beta_{4} F D I_{i t}+\beta_{5} G O V E X P_{i t}+\beta_{6} D E B T_{i t}+\beta_{7} I N V G_{i t}+\beta_{8} I N V D_{i t}+ \\
& \beta_{9} C P I_{i t}+\beta_{10} L O A N_{i t}+\beta_{11} E U_{i t}+\beta_{12} C R I S_{i t}+ \\
& \beta_{13}\left(\frac{y_{i t-1)}^{S E E}}{y_{(t-1)}^{E U}}\right)
\end{aligned}
$$

The dependent variable is the adjusted gross disposable income of households per capita SEE country $i(i=1, \ldots, 8)$ in year $\mathrm{t}$ as a percentage of the EU average. For robustness purposes and to control for short-run fluctuations, we also estimate the model for average gross disposable income over 3-year periods as the dependent variable. The regression employs country-fixed effects $\left(\alpha_{i}\right)$ to control for the effects of unobserved confounding variables that vary across countries and years. Regressors in the model are chosen based on the standard growth literature. (Salai-Martin, 1997; Durlauf and Quah, 1999; Temple, 1999). Our dependent variable measures income convergence per capita towards the EU benchmark over time.

As independent variables, we used different factors which can increase or decrease the rate of convergence. Human capital is represented by average years of total schooling $(\mathrm{SCH})$ for individuals aged 15 years and above (see, i.e. Barro and Lee, 2013) and unemployment level (UNEMPL). We suppose thet SCH positively influences income convergence, while it is opposite for unemployment. Fiscal policy is approximated by government expenditures as the percentage of GDP (GOVEXP) and public debt (DEBT). We believe that GOVEXP stimulates income convergence, while public debt generates income divergence. External forces are represented by the level of foreign trade (FTR), calculated as the sum of exports and imports, and by net inflow of the foreign direct investment (FDI). Investments are separated into public (INVG) and domestic private investments

$\overline{6}$ We use data-driven bandwidth selection and an Epanechnikov kernel function. 
(INVD). We assume that investments and FTR are influencing positively income convergence. Monetary policy is approximated by price instability and measured as the annual rate of the consumer prices index (CPI), and we expect that impact on income convergence is negative. The financial sector and financial depending are approximated by the level of credits to the private sector (LOAN), which can positively influence income convergence. All investments and credits, as well as fiscal variables and foreign trade, are expressed as a percentage of GDP.

Finally, we include dummy variables for the years in which a SEE country was a member of the EU (EU) and for the years of the global crises (CRIS). Membership in the EU takes the value of 1 if a SEE country is an EU member in that year, and 0 otherwise. The "years of the global crises" takes the value of 1 during the 2009-2010 period and 0 otherwise. Finally, we included lagged values of the dependent variable in order to conclude about the persistency of the convergence process.

\section{Empirical data and analysis}

The sample covers eight countries in SEE during the period 2000-2018. The adjusted gross disposable income of households per capita reflects the purchasing power of households and their ability to invest in goods and services or save for the future. It is calculated as the adjusted gross disposable income of households divided by the purchasing power parities (PPP) of the actual individual consumption of households and by the total resident population. The index is calculated with the European Union average set to equal 100. If the index of a country is higher than 100, this country's level of adjusted gross disposable income of households per person is higher than the EU average and vice versa. Variables were collected from the World Bank's World Development Indicators database and Eurostat. ${ }^{7}$ Data sets are analysed using STATA software. The descriptive statistics for all variables are shown in Table 1.

\footnotetext{
7 Source for dependent variable is EUROSTAT, online data code SDG_10_20.
} 
Table 1: Descriptive statistics ${ }^{8}$

\begin{tabular}{|l|c|c|c|}
\cline { 2 - 4 } \multicolumn{1}{c|}{} & $2000-2018$ & $2000-2008$ & $2009-2018$ \\
\hline $\begin{array}{l}\text { Average income per capita } \\
\text { (\% of EU average) }\end{array}$ & 37.62 & 32.28 & 42.44 \\
\hline Average income per capita & $(11.96)$ & $(10.83)$ & $(10.89)$ \\
\hline$\%$ of EU average), t-1 & 37.18 & 31.27 & 41.92 \\
\hline Unemployment rate & $(11.80)$ & $(10.29)$ & $(10.80)$ \\
(in \%) & 17.84 & 19.16 & 16.66 \\
\hline FDI (\% of GDP) & $(8.56)$ & $(9.53)$ & $(7.46)$ \\
\hline Foreign trade (sum import and export & 5.89 & 6.89 & 4.99 \\
in \% of GDP) & $(4.36)$ & $(4.76)$ & $(3.78)$ \\
\hline Public debt (\% of GDP) & $(18.75$ & 84.18 & 94.77 \\
& 45.70 & $(18.17)$ & $(17.66)$ \\
\hline Domestic private investments & $(23.94)$ & 42.67 & 48.34 \\
(\% of GDP) & 16.97 & $128.48)$ & $(18.89)$ \\
\hline Public investments (\% of GDP) & $(5.37)$ & $(5.42)$ & 17.11 \\
\hline CPI (in \%) & 4.65 & 4.72 & $(5.37)$ \\
\hline Government expenditures & $(1.67)$ & $(1.57)$ & $(1.77)$ \\
(\% of GDP) & 5.67 & 9.63 & 2.11 \\
\hline Credits to private sector & $(11.17)$ & $(15.14)$ & $(2.34)$ \\
(\% of GDP) & 18.11 & 18.82 & 17.47 \\
\hline Average years of schooling & $(3.86)$ & $(4.23)$ & $(3.40)$ \\
\hline
\end{tabular}

Source: Author's calculation according to data obtained from WB and Eurostat

The average per-capita income in SEE was $37 \%$ of the EU average. Five variables - unemployment rate, FDI, public investment, inflation and government expenditures - decreased between the first and second sample periods. The average gross income in SEE was in the period 2000-2008 around 10 percentage points lower than in the second period. Parallel to that, the unemployment rate was lower, as well as the level of foreign trade. The price liberalization caused relatively high levels of inflation in the 2000s during that phase of transition in SEE. Moderate public spending in the second period (government expenditures and public investment), lower foreign direct investments, and a higher level of public debt was most probably the result of the global financial crisis in Europe in the 2009-2010 period.

$\overline{8}$ The reported numbers are averages across all countries and years. Standard deviations are in parenthesis. 
To choose a regression technique, we first tested autocorrelation in panel data using the Wooldridge test (Wooldridge, 2002). Results show that first-order autocorrelation is present ( $\mathrm{Prob}>\mathrm{F}=0.002$ for $2000-2018$ period; $\mathrm{Prob}>\mathrm{F}=0.010$ for 2000-2008 period; Prob $>\mathrm{F}=0.0014$ for 2009-2018 period;). Modified Wald test for groupwise heteroskedasticity in fixed effects $(\mathrm{FE})$ regression model shows that heteroskedasticity is present for all dependent variables. Finally, taking into consideration that in our panel, $\mathrm{N}$ is bigger than $\mathrm{T}(\mathrm{N}=1,216 ; \mathrm{T}=10)$, we tested cross-sectional dependence using the test of Pesaran (2004). Results show no presence of cross-sectional dependence in our panel.

Table 2: Heteroskedasticity tests results

\begin{tabular}{|c|c|}
\hline Variables & Modified Wild Test \\
\hline Average income per capita (\% of EU average), 2000-2018 & $\begin{array}{c}1,594.16 \\
(0.000)\end{array}$ \\
\hline Average income per capita (\% of EU average), 2000-2008 & $\begin{array}{c}85.16 \\
(0.000)\end{array}$ \\
\hline Average income per capita (\% of EU average), 2009-2018 & $\begin{array}{c}283.98 \\
(0.000)\end{array}$ \\
\hline
\end{tabular}

Source: Author's calculation according to data obtained from WB and Eurostat

Recent literature dealing with the estimation of heterogeneous panels (Baltagi et al., 2006; Baltagi et al., 2010) suggests that, if heteroskedasticity is present, the choice of a relevant model is sensitive to specifying the correct source of heteroskedasticity. Starting from that, and also taking into consideration that firstorder autocorrelation is present, based on the conclusions of Hoechle (2007), we will use in our analysis fixed effects linear panel regression with robust standard error. $^{9}$

\subsection{Distribution dynamics}

The density distributions of average gross income per capita as \% of the EU average for the pre-crisis period (years 2000, 2004 and 2008) are presented in Figure 1. At the start of the observed period in 2000, the density distribution was almost unimodal, with most of the probability mass concentrated in the range between $20 \%$ and $30 \%$ of the EU average, with a minor mode emerging at the $50 \%$ level. Over the following eight years, there is a clear shift of the distribution to the

${ }_{9}$ It is also possible to use FGLS regression, but that method is infeasible if the panel's time dimension $\mathrm{T}$ is smaller than its cross-sectional dimension $\mathrm{N}$ (Hoechle, 2007), which it is in our case. 
right, signifying convergence to the benchmark. Also, an increase in the dispersion of average income per capita produces a new range at around $30-45 \%$ of the EU average. Simultaneously, a minor mode emerges at the $60 \%$ level suggesting some level of convergence between SEE countries.

Figure 1: Kernel density distributions of average gross income per capita (\% of EU average), 2000-2008

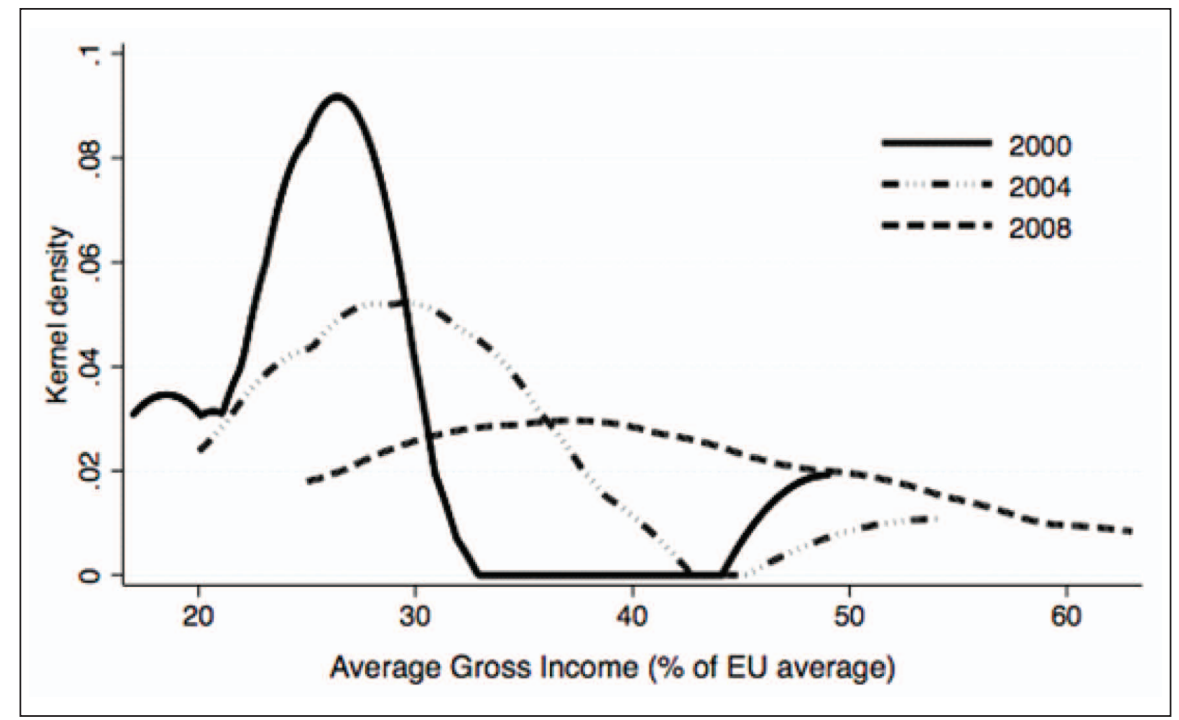

Source: Author's calculation according to data obtained from WB and Eurostat

The observed convergence over the first decade of the 2000s correlates with the most dynamic period of the transition in SEE, when many economies in the region experienced high growth rates and significant investments, especially FDIs. The strong convergence tendency of the late 2000s reflects the success of political reforms in generating growth that allowed SEE countries to catch up with the EU. At the end of this period, two countries (Romania and Bulgaria) became members of the EU.

The distributional dynamics in the period after 2009 present a slightly different picture. The density distributions of average gross income per capita as $\%$ of the EU average for the crisis and post-crisis period (years 2009, 2013 and 2018) are presented in Figure 2. 
Figure 2: Kernel density distributions of average gross income per capita (\% of EU average), 2009-2018

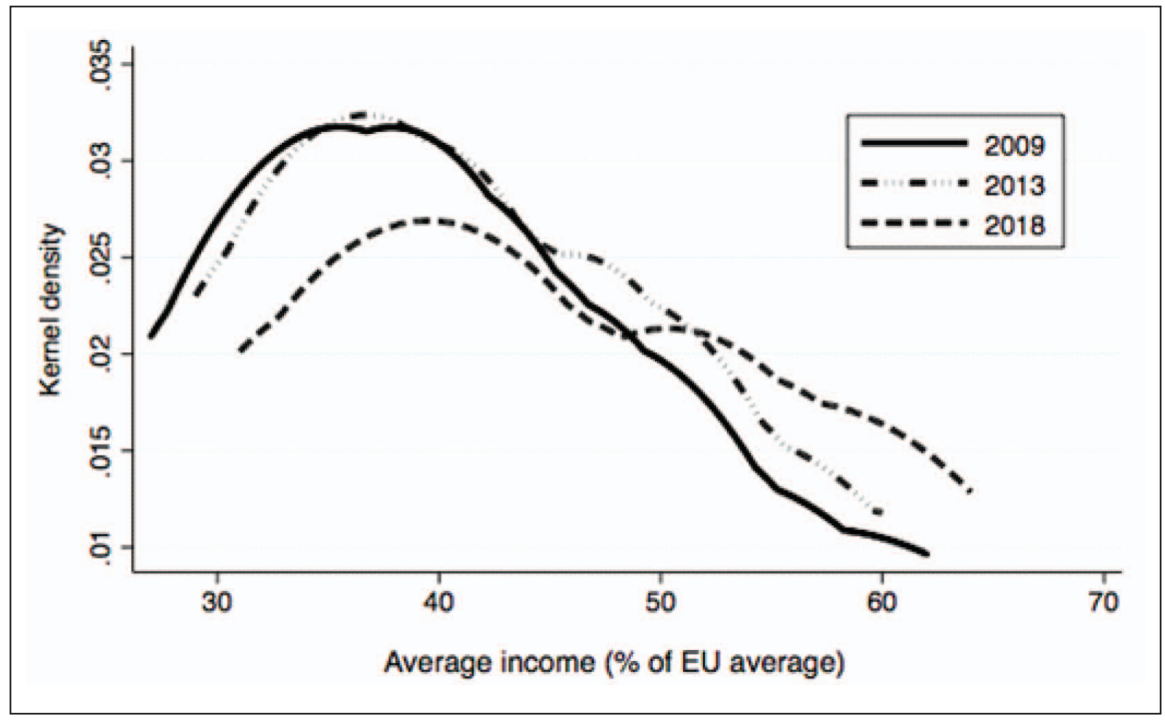

Source: Author's calculation according to data obtained from WB and Eurostat

This period started with an economic crisis that heated the whole of Europe. A continuous shift of the distribution to the right, started in the previous period, was slowed, discontinuing the convergence between SEE and the EU benchmark. In the next five years, distribution remains similar, between $30-45 \%$ of the EU benchmark. In the last five years of the observed period, we can see significant convergence again. In that period, distribution was shifted to the right again, with most of the probability mass concentrated around $40 \%$ of the EU average. At the same time, we see some modes around $50 \%$, and minor modes around $60 \%$. These include mostly EU member countries in the SEE, such as Romania, Bulgaria and Croatia, as well as Montenegro. Although they experienced an increase in income per capita, the speed of convergence was moderate compared to the first period when most of the SEE countries doubled average gross income per capita measured in \% of EU average. For instance, in the first observed period, countries like Bulgaria achieved a 55\% increase in its relative standing while Montenegro reached a $62 \%$ increase. Also, not all countries experienced the same dynamics in the second period. Serbia recorded a $2.6 \%$ increase in its relative standing over the period 2009-2018, better than Croatia (1.6\%) similar with Bosnia-Herzegovina (3.3\%), but far behind North Macedonia (11.8\%), Albania (14.8\%), Bulgaria (16.3\%), Montenegro (17.5\%) or Romania (23.1\%). 


\subsection{Regression results}

Regression analysis results are in line with the previous findings. The results for model specification of the fixed-effects over the entire sample period and two subperiods are shown in Table 3. We should note again that the dependent variable measures income convergence (or divergence) between SEE and the EU over time.

Table 3: Regression results for average gross income per capita GDP in \% of EU average

\begin{tabular}{|l|c|c|c|}
\cline { 2 - 4 } \multicolumn{1}{l|}{} & $2000-2018$ & $2000-2008$ & $2009-2018$ \\
\hline Average Income & $1.007^{*}$ & $0.951^{*}$ & $0.959^{*}$ \\
(t-1) & $(0.014)$ & $(0.107)$ & $(0.017)$ \\
\hline Unemployment rate & -0.019 & $-0.039^{* *}$ & $-0.0 .097^{*}$ \\
(UNEMPL) & $(0.022)$ & $(0.199)$ & $(0.032)$ \\
\hline FDI & $0.084^{*}$ & 0.015 & $0.081^{* *}$ \\
& $(0.022)$ & $0.038)$ & $(0.054)$ \\
\hline Foreign trade & $-0.023^{*}$ & 0.003 & -0.008 \\
(FTR) & $(0.009)$ & $(0.008)$ & $(0.010)$ \\
\hline Public debt & $-0.029^{*}$ & -0.003 & -0.003 \\
(DEBT) & $(0.008)$ & $(0.009)$ & $(0.008)$ \\
\hline Domestic private investments & $0.347^{*}$ & $0.321^{* *}$ & $0.425^{* *}$ \\
(INVD) & $(0.027)$ & $0.018)$ & $(0.029)$ \\
\hline Public investments & 0.083 & $0.285^{*}$ & 0.016 \\
(INVG) & $(0.076)$ & $(0.076)$ & $(0.064)$ \\
\hline CPI & $-0.018^{* *}$ & -0.004 & $-0.062^{* *}$ \\
\hline Government expenditures & $(0.009)$ & $(0.003)$ & $(0.034)$ \\
(GOVEXP) & 0.001 & $-0.212^{*}$ & $0.225^{*}$ \\
\hline Credits to private sector & $(0.039)$ & $(0.027)$ & $(0.099)$ \\
(LOAN) & 0.001 & $0.025^{*}$ & $-0.041^{*}$ \\
\hline Average years of schooling & $(0.006)$ & $(0.008)$ & $(0.025)$ \\
(SCH) & $0.171^{*}$ & $1.974^{*}$ & $-0.873^{*}$ \\
\hline EU Membership & $(0.021)$ & $(0.351)$ & $(0.181)$ \\
(EU) & $0.273^{*}$ & 0.389 & $1.198^{*}$ \\
\hline Economic Crisis & $(0.032)$ & $(0.479)$ & $(0.529)$ \\
(CRIS) & $-1.533^{*}$ & & $-0.996^{*}$ \\
\hline Const. & $(0.285)$ & & $(0.393)$ \\
\hline No of Observation & 2.836 & $-19.420^{*}$ & $14.020^{*}$ \\
\hline & $(2.332)$ & $(5.171)$ & $(3.108)$ \\
\hline & 141 & 62 & 79 \\
\hline
\end{tabular}

* 5\% significance level; ** 10\% significance level

Source: Author's calculation according to data obtained from WB and Eurostat 


\section{Results and discussion}

The regression analysis shows that progress in EU integration, education (average years of schooling) and investments (FDI and public investment) were the key determinants of convergence over the entire sample period while divergence was mainly driven by the economic crisis and by the unemployment rate growth after the economic crisis 2009-2010.

Membership in the EU contributes to the accelerated economic growth and faster convergence (Ryszard and Mariusz, 2019; Alcidi, 2019; Cuaresma et al., 2008). In the case of SEE countries, that is most evident for Romania, Bulgaria, and Croatia. At the same time, average years of schooling promotes not only economic growth but also convergence towards the EU average per capita income (Henderson and Russell, 2005). Based on the comparative analysis of the education quality significance to economic growth (Hanushek and Woessmann, 2010) it is logical to assume that the education quality has improved alongside increased years of schooling in SEE. The educated workforce helped SEE to grow more rapidly than the EU benchmark. Many factors might be responsible for this, including the historical quality of education in SEE as well as enhanced opportunities for higher income in the booming private sector (2001-2008) in comparison to the salaries in the public sector. However, this effect seems to be limited to the first period of transition, while in the second period, with higher levels of development, some other factors become more important. That is also influenced by the massive brain drain from SEE, especially in the period after the crisis.

The impact of FDI on convergence in the whole observed period is positive. In economic literature, there is a clear consensus that FDI contributes to living standards (OECD, 2008). Hence, some analysis shows that the result depends "positively on levels of freedom from government intervention and freedom from business regulation, and negatively on FDI volatility and natural resource dependence" (Herzer, 2012). We assume that FDI flow in the SEE region is mostly driven by a cheap labour force, while markets are unstable and highly dependent on government intervention. In such an environment, FDI contributes to the average income growth, but much less than expected. At the same time, the contribution of private domestic investment is significant, especially in the second period. Most of the literature points out this factor as critical for growth and convergence toward the EU standard (Grela et al., 2017).

A positive sign for the coefficient of financial depending (LOAN) is not unexpected, taking in consideration previous studies for this region (Kiss et al. 2006; Stojanović and Stojanović, 2015). Between 2000 and 2008, most of the SEE countries experienced an unprecedented credit boom with double-digit increases in private lending as a share of GDP. Credit growth was fuelled by large inflows resulting from the high liquidity on global markets that was channelled into SEE via foreign- 
owned banks that dominate the financial sector in many countries in the region (IMF, 2015; IMF, 2017). Presence of foreign banks made it possible to increase the availability of funds to the private sector in these countries. The credit boom disappeared as soon as the global crisis hit the region in 2009-2010. SEE countries, which had experienced massive private credit growth in the years 2000-2008, in the second period faced a drop or a slowdown in the convergence of their per-capita income compared to the EU average.

In the period after the crisis, most of the countries established expansive fiscal policies to fasten economic growth and fight economic crisis. On the other side, significant level of government expenditures is followed by high public debt. Although the literature on the relationship between government debt and economic growth in the period of crisis and after crisis (Darvas, 2010; Checherita-Westphal and Rother, 2011), shows a certain positive correlation between fiscal expenditures, public debt, and growth, that is true until a certain threshold is reached. All countries (except Bulgaria) experience high levels of public debt, which hampered the income convergence of the region.

Our results also show that the global economic crisis has slowed down the convergence of the SEE region. That result is in line with economic literature (Matkowski et al. 2016; Stanisic, 2012). During the crisis, most of the convergence drivers (investments, EU integration process, credit to the private sector) dramatically slowed, creating increased income differences between SEE and EU countries. Moreover, the scope and duration of this effect have affected the mediumterm convergence path, as we can see from the results in the second period (Table $3)$. Although the temporary nature of the crises is evident, this conclusion is in line with our finding in the nonparametric part of the analysis that showed convergence to be generally affected by the crises.

At the same time, unemployment played an important role in income divergence in the SEE region over time as well as inflation. In particular, increases in inflation cause average per capita income in SEE to diverge from the EU average. Inflation is more generally a sign of macroeconomic instability, especially in SEE, where hyperinflation has resulted from price liberalisation in the early stages of the first period as well as from banking and financial crises due to the expansionary monetary policy. Therefore, it is not unexpected that this instability hampers the reduction of disparities between SEE and the EU.

The results indicate faster income convergence to the EU average in the early years of transition (2000-2008). During this period, SEE countries, on average, doubled their average per-capita income comparing the benchmark. Some countries, like Romania and Bulgaria, entered the EU at the end of this period, which highly influenced their income level. Simultaneously, the relative income distribution over this period evolved from a multimodal to a unimodal one, hiding a disparity among 
the countries in the sample. Over the years 2009-2010, SEE countries experienced economic crises, which slowed down the convergence. Our analysis shows that in the 2009-2018 period, SEE countries did not retrieve convergence dynamics from the previous period. At the same time, the global crises influenced convergence tendencies but also increased relative income heterogeneity across the region, especially between EU and non-EU countries.

\section{Conclusions}

Our analysis shows that income convergence in SEE countries was inadequate in the 2000-2018 period. At the same time, over the first eight years (2000-2008), there was a clear and dynamic convergence to the EU benchmark. That convergence process was interrupted by an economic crisis in 2009, discontinuing the convergence between SEE and the EU benchmark after 2010. EU integration has been one of the primary goals in SEE over the past two decades and tends to remain the main priority in the future. Several countries in the region have succeeded in joining the EU (Romania, Bulgaria, and Croatia), while others are candidates and should become members in the future. However, SEE countries still rank at the bottom in per capita income terms. It seems that the growth model dominant in the SEE region in the period before the crisis, based on a large inflow of FDI, has reached its limits. This leads us to the SEE countries' economic policies' need to focus more on promoting domestic private investments as one of the crucial factors for income convergence in the coming years. Apart from that, growth and convergence need to be driven by other factors affecting structural competitiveness, such as innovation, institutional environment and policies, and demographic developments important for the labour market outcomes. Finally, to better understand individual countries, analysis of the specific countries' income convergence drivers should be further explored.

\section{References}

Abiad, A., Leigh, D., Mody, A. (2007) "International Finance and Income Convergence: Europe is Different", IMF Working Paper, European Department, Available at: https://www.imf.org/external/pubs/ft/wp/2007/wp0764.pdf.

Alcidi, C. (2019) "Economic Integration and Income Convergence in the EU", Intereconomics, Vol. 54, No. 1, pp. 5-11, https://doi.org/10.1007/s10272-0190783-6.

Alho, K. E. O., Kaitila, V., Widgrén, M. (2004) "Speed of convergence and relocation: New EU member countries catching up with the old", ETLA Discussion Papers, No. 963, The Research Institute of the Finnish Economy (ETLA), Helsinki, http:// hdl.handle.net/10419/63930. 
Baltagi, B.H., Bresson, G., Pirotte, A. (2006) "Joint LM test for homoscedasticity in a one-way error component model", Journal of Econometrics, Vol. 134, pp. 401-417, https://doi.org/10.1016/j.jeconom.2005.06.029.

Baltagi, B.H., Jung, B.C., Song, S.H. (2010) "Testing for heteroskedasticity and serial correlation in a random effects panel data model", Journal of Econometrics, Vol. 154, No. 2, pp. 122-124, https://doi.org/10.1016/j.jeconom. 2009.04.009.

Barro, R. J., Sala-i-Martin, X. (1990) Economic growth and convergence across the United States, No. w3419, National Bureau of Economic Research, https://doi. org/10.3386/w3419.

Barro, R., Lee, J. (2013) "A new data set of educational attainment in the world, 1950-2010", Journal of Development Economics, Vol. 104, pp. 184-198, https://doi.org/10.1016/j.jdeveco.2012.10.001.

Bartlett W. (2009) "Economic development in the Europeans upper-periphery: evidence from the Western Balkans", Economic Annals, Vol. 54, No. 181, pp. 21-44, https://doi.org/10.2307/2595100.

Ben-David, D. (1996) "Trade and convergence among countries", Journal of International Economics, Vol. 40, pp. 279-298, https://doi.org/10.1016/00221996(95)01405-5.

Borsi, M. T., Metiu, N. (2015) "The evolution of economic convergence in the European Union", Empirical Economics, Vol. 48, No. 2, pp. 657-681, https:// doi.org/10.1007/s00181-014-0801-2.

Carlino, A. G., Mills, L. (1996) "Testing neoclassical convergence in regional incomes and earnings", Regional Science and Urban Economics, Vol. 26, pp. 565-590, https://doi.org/10.1016/S0166-0462(96)02137-0.

Checherita-Westphal, C., Rother. P. (2011) "The Impact of Government Debt on Growth. An Empirical Investigation for the Euro Area", Revue économique, Vol. 62, No. 6, pp. 1015-1029, https://www.jstor.org/stable/41307971.

Choi, C. (2004) "Foreign direct investment and income convergence", Applied Economics, Vol. 36, No. 10, pp. 1045-1049, https://doi.org/10.1080/000368404 2000246759.

Cuaresma, J.C., Ritzberger-Grunwald, D., Silgoner M.A. (2008) "Growth, Convergence and EU Membership", Applied Economics, Vol. 40, No. 5, pp. 643-656, https://doi.org/10.1080/00036840600749524.

D'Elia, E., De Santis, R. (2019) "Growth divergence and income inequality in OECD countries: the role of trade and financial openness", LEQS Paper, Vol. 148, http://aei.pitt.edu/id/eprint/102415.

Darvas, Z. (2010) "The Impact of the Crisis on Budget Policy in Central and Eastern Europe", OECD Journal on Budgeting, Vol. 10, No. 1, pp. 39-80, https://doi.org/10.1787/budget-10-5km7s5m3nlvd. 
De Dominicis, L. (2014) "Inequality and growth in European regions: Towards a place-based approach", Spatial Economic Analysis, Vol. 9, No. 2, pp. 120-141, https://doi.org/10.1080/17421772.2014.891157.

Dobson, S., Ramlogan, C. (2002) "Convergence and divergence in Latin America, 1970-1998”, Applied Economics, Vol. 34, pp. 465-470, https://doi.org/ 10.1080/00036840600606278.

Drezgić, S. (2011) "Public investments and regional income convergence: empirical analysis of Croatian regions", Social Research, No. 3 (24), pp. 43-55, Available at: http://www.su.lt/bylos/mokslo_leidiniai/soc_tyrimai/2011_24/drezgic.pdf.

Durlauf, S. N., Quah, D. (1999) "The New Empirics of Economic Growth", in: Taylor, J.B. and Woodford, M. (Eds.), Handbook of Macroeconomics, Vol. 1A, North Holland, Amsterdam, pp. 235-308, https://doi.org/10.3386/w6422.

Eckey, H., Türck, M. (2005) "Convergence of EU regions: A literature report", Volkswirtschaftliche Diskussionsbeiträge, No. 80, Universität Kassel, Fachbereich Wirtschaftswissenschaften, Kassel, http://hdl.handle.net/10419/32143.

European Commission (2003) Western Balkans in Transition, European Commission's Directorate General for Economic and Financial Affairs, Brussels, Available at: https://ec.europa.eu/economy_finance/publications/ pages/publication15155_en.pdf.

Greasley, D. and Oxley, L. (1997) "Time-series based tests of the convergence hypothesis: some positive results", Economics Letters, Vol. 56, pp. 143-147, https://doi.org/10.1016/S0165-1765(97)81892-7.

Grela, M. et al. (2017) "Is Central and Eastern Europe converging towards the EU15?”, NBP Working Paper No. 264, National Bank of Poland, Available at: https://www.nbp.pl/Publikacje/Materialy_I_Studia/264_En.Pdf.

Hanushek E. A. and Wößmann L. (2010) "Education and Economic Growth", In: Penelope Peterson, Eva Baker, Barry McGaw (Editors), International Encyclopedia of Education, Volume 2, pp. 245-252, Oxford: Elsevier, Available at: http://hanushek.stanford.edu/sites/default/files/publications/ Hanushek\%2BWoessmann\%202010\%20IntEncEduc\%202.pdf.

Henderson D., Russell R. (2005) "Human capital and convergence: A productionfrontier approach", International Economic Review, Vol. 46, No. 4, pp. 11671205, https://www.jstor.org/stable/3663664.

Herzer, D. (2012) "How does foreign direct investment really affect developing countries' growth?", Review of International Economics, Volume 20, Issue 2, pp. 396-414, https://doi.org/10.1111/j.1467-9396.2012.01029.x.

Hoechle, D. (2007) "Robust standard errors for panel regressions with crosssectional dependence", The Stata Journal, Vol. 7, No. 3, pp. 281-312, https:// doi.org/10.1177/1536867X0700700301.

IMF (2015) The Western Balkans: 15 years of economic transition, Regional Economic Issues, Special Report, International Monetary Fund, Washington, 
DC, Available at: https://www.imf.org/external/pubs/ft/reo/2015/eur/eng/erei 0315.htm.

IMF (2017) A broadening recowery, Central, Eastern, and Southeastern Europe, Regional Economic Issues, International Monetary Fund, Washington, DC, Available at: https://www.imf.org/en/Publications/REO/EU/Issues/2017/05/10/ a-broadening-recovery.

Krestovska, A. (2018) "Real Convergence of Western Balkan Countries to European Union in view of Macroeconomic Policy Mix", Journal of Central Banking Theory and Practice, pp.187-202, https://doi.org/10.2478/jcbtp-2018-0018.

Kiss, G., Márton N., Balázs V. (2006) "Credit Growth in Central and Eastern Europe: Convergence or Boom?," MNB Working Papers 2006/10, Magyar Nemzeti Bank - Central Bank of Hungary, Available at: http://hdl.handle. net $/ 10419 / 83593$.

Kutan, A. M., Yigit, T. M. (2009) "European integration, productivity growth and real convergence: Evidence from the new member states", Economic Systems, Vol. 33, No. 2, pp. 127-137, https://doi.org/10.1016/j.ecosys.2009.03.002.

Li, Q., Racine, J. S. (2007) Nonparametric Econometrics: Theory and Practice, Princeton University Press.

Linden, M. (2002) "Trend model testing of growth convergence in 15 OECD countries, 1946- 1997", Applied Economics, Vol. 34, pp. 133-142, https://doi. org/10.1080/00036840010025119.

Martin, C., Valazquez, F. J., Bernard, F. (2001) "European Integration and income convergence Lessons for Central and Eastern European Countries", World Bank Technical Paper No. 514, European and Central Asia Poverty Reduction and Economic Management Series, https://doi.org/10.1596/978-0-8213-4994-6.

Matkowski, Z., Prochniak, M., Rapacki, R. (2016) "Real Income Convergence between Central Eastern and Western Europe: Past, Present, and Prospects", 33rd CIRET Conference on Economic Tendency Surveys and Economic Policy Copenhagen, Denmark, http://hdl.handle.net/10419/146992.

Nenovsky, N., Tochkov, K. (2014) "Transition, Integration and Catching Up: Income Convergence between Central and Eastern Europe and the European Union", Mondes en développement, Vol. 167, pp. 73-92, https://doi.org/10.3917/ med.167.0073.

Niebuhr, A., Schlitte, F. (2004) "Convergence, trade and factor mobility in the European Union: Implications for enlargement and regional policy", Intereconomics, ISSN 0020-5346, Springer, Heidelberg, Vol. 39, No. 3, pp. 167-176, https://doi.org/10.1007/BF02933584.

OECD (2008) "The impact of foreign direct investment on wages and working conditions", OECD-ILO conference on corporate social responsibility, Paris, France, https://doi.org/10.1787/230184240223. 
Paas, T., Schlitte, F. (2006) "Regional Income Inequality and Convergence Processes in the EU-25", HWWA Discussion Paper, No. 355, Hamburg Institute of International Economics, https://www.researchgate.net/publication/23731981_ Regional_Income_Inequality_and_Convergence_Processes_in_the_EU-25.

Pesaran, M. H. (2004) "General diagnostic tests for cross section dependence in panels", Working Papers in Economics No. 0435, Cambridge: University of Cambridge, Faculty of Economics, https://doi.org/10.1007/s00181-020-018757.

Quah, D. (1993) "Empirical cross-section dynamics in economic growth", European Economics Review, Vol. 37, pp. 426-434, https://doi.org/10.1016/0014-2921(93) 90031-5.

Quah, D. (1996a) "Empirics for economic growth and convergence", European Economic Review, Vol. 40, pp.1353-1375, https://doi.org/10.1016/0014-2921(95) 00051-8.

Quah, D. (1996b) "Twin Peaks: growth and convergence in models of distribution dynamics", Economic Journal, Vol. 106, pp. 1045-1055, https://doi.org/ $10.2307 / 2235377$.

Quah, D. (1997) "Empirics for growth and distribution: stratification, polarization and convergence clubs", Journal of Economic Growth, Vol. 2, pp. 27-59, https://doi.org/10.1023/A:1009781613339.

Rassekh, F., Panik, M. J., Kolluri, B. R. (2001) "A test of convergence hypothesis: the OECD experience, 1950-1990", International Review of Economics and Finance, Vol. 10, pp. 147-157, https://doi.org/10.1016/S1059-0560(01)00079-X.

Rubinic, I., Tajnikar, M. (2019) "Labour Force Exploitation and Unequal Labour Exchange as the Root Cause of the Eurozone's Inequality", Društvena istraživanja, Vol. 28, No. 2, pp. 207-228, https://www.ceeol.com/search/articledetail?id=799967.

Rubinic, I., Tajnikar, M. (2020) "The influence of the economic cycle on Eurozone cross- country inequality dynamics", South-Eastern Europe Journal of Economics, Association of Economic Universities of South and Eastern Europe and the Black Sea Region, Vol. 17, No. 2, pp. 267-290, https://ojs.lib.uom.gr/ index.php/seeje/article/view/9644.

Ryszard, R., Mariusz, P. (2019) "EU membership and economic growth: empirical evidence for the CEE countries", European Journal of Comparative Economics, Cattaneo University, Vol. 16, No. 1, pp. 3-40, http://ejce.liuc.it/1824297920190 1/182429792019160101.pdf.

Sala-i-Martin, X. (1997) "I just ran two million regression", American Economic Review, Vol. 87, pp. 178-183, https://www.jstor.org/stable/2950909.

Sanfey, P., Milatovic, J. (2018) "The Western Balkans in transition: diagnosing the constraints on the path to a sustainable market economy", Background paper for the Western Balkans Investment Summit, hosted by the EBRD, 26 February 
2018, https://www.ebrd.com/documents/eapa/western-balkans-summit-2018diagnostic-paper.pdf.

Simionescu, M. (2015) "About regional convergence clubs in the European Union", Zbornik radova Ekonomskog fakulteta Rijeka, Vol. 33, No. 1, pp. 67-80, https:// hrcak.srce.hr/139926.

Stanisic, N.M. (2012) "The effects of the economic crisis on income convergence in the European Union", Acta Oeconomica, Vol. 62, No. 2, pp. 161-182, https:// doi.org/10.1556/aoecon.62.2012.2.2.

Stojanović, D., Stojanović, D. (2015) "Excessive credit growth or the catching up process: the case of Central, Eastern, and South-eastern European countries", Economic annals, Vol. 60, No. 208, pp. 7-44, https://doi.org/10.2298/EKA $1506007 \mathrm{~S}$.

Temple, J. (1999) "The new growth evidence", Journal of Economic Literature, Vol. 37, pp. 112-156, https://doi.org/10.1257/jel.37.1.112.

Tselios, V. (2009) "Growth and convergence in income per capita and income inequality in the regions of the EU", Spatial Economic Analysis, Vol. 4, No. 3, pp. 343-370, https://doi.org/10.1080/17421770903114711.

Uvalic, M (2010) "Transition in Southeast Europe: Understanding economic development and institutional change", WIDER Working Paper, No. 2010/41, https://doi.org/10.1057/9780230361836_15.

Vojinovic, B., Acharya, S., Prochniak, M. (2009) "Convergence analysis among the ten European transition economies", Hitotsubashi Journal of Economics, Vol. 50, No. 2, pp. 17-35, https://www.jstor.org/stable/43296221.

Wooldridge, J. M. (2002) Econometric Analysis of Cross Section and Panel Data, Cambridge, MA: MIT Press.

Yin, L, Zestos, G. K., Michelis, L. (2003) "Economic Convergence in the European Union", Journal of Economic Integration, Vol. 18, No. 1, pp. 188-213, https:// www.jstor.org/stable/23000737.

Zhang, Z., Liu, A., Yao, S. (2001) “Convergence of China's regional incomes 19521997”, China Economic Review, Vol. 12, pp. 243-258, https://doi.org/10.1016/ S1043-951X(01)00053-0. 


\title{
Dohodovna konvergencija Jugoistočne Europe i Europske unije
}

\author{
Goran Radosavljević ${ }^{1}$, Mihajlo Babin ${ }^{2}$, Miloš Erić ${ }^{3}$, Jelisaveta Lazarevićc
}

\begin{abstract}
Sažetak
Ovaj rad analizira prosječnu bruto per capita dohodovnu konvergenciju osam zemalja Jugoistočne Evrope (JIE) prema prosjeku EU-a. Cilj je utvrditi koji faktori doprinose konvergenciji zemalja JIE regije kao i opisati kretanje konvergencije u periodu 2000.-2018. godine, s posebnom pozornošću na dva pod perioda, prije $i$ nakon Svjetske ekonomke krize. Koristimo pri tome kombinaciju parametarskih i neparametarskih metoda i linearne panel regresije fiksnih efekata s robusnim standardnim greškama. Rezultati sugeriraju da je konvergencija bila podstaknuta procesom EU integracija, obrazovnim nivoom stanovništva, investicijama (stranim, domaćim i javnim), kreditnom ekspanzijom u privatnom sektoru, kao $i$ rastom javnih rashoda. S druge strane, ekonomska kriza, nezaposlenost i inflacija bili su glavni faktori koji su utjecali na divergenciju procesa. Zaključujemo na kraju i da je post-tranzicijski model rasta dominantan u regiji SEE, temeljen na stranim direktnim investicijama, nedovoljan, i da su domaće privatne investicije kritično-nedostajući faktor brže dohodovne konvergencije.
\end{abstract}

Ključne riječi: bruto dohodovna konvergencija, Jugoistočna Europa, ekonomski rast, EU integracije, analiza panela

JEL klasifikacija: F43, O11, O47

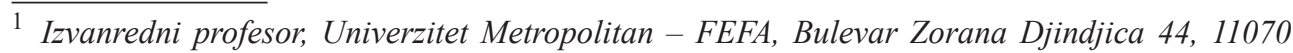
Beograd, Srbija. Znanstveni interes: javne financije, mikroekonomija, energetsko gospodarstvo. Tel.:+381694777605.E-mail: gradosavljevic@fefa.edu.rs.

2 Izvanredni profesor, Univerzitet Metropolitan - FEFA, Bulevar Zorana Djindjica 44, 11070 Beograd, Srbija. Znanstveni interes: gospodarski razvoj, fiskalna politika. Tel.: +381694777605.E-mail:mbabin@fefa.edu.rs.

3 Docent, Univerzitet Metropolitan - FEFA, Beograd, Srbija. Znanstveni interes: Europske ekonomske integracije, gospodarskirazvoj.Tel.: +381694777605.E-mail:meric@fefa.edu.rs.

4 Asistentica, Univerzitet Metropolitan - FEFA, Bulevar Zorana Djindjica 44, 11070, Beograd, Srbija. Znanstveni interes: financijska tržišta, konkurentnost. Tel.: +381694777605. E-mail: jlazarevic@fefa.edu.rs. 